\title{
VÁLASZÚT ELŐTT A REGIONÁLIS POLITIKA
}

\author{
Horváth Gyula
}

1. A keynesiánus eszmerendszer baloldali áramlatához tartozóKáldor Miklós 1970-ben a Skót Közgazdasági Társaság 5. közgyúlésén The Case for Regional Policies címmel tartott elốadást. A brit konzervatív erôk idóleges előretörése idején a szigetország alulfejlett régiójában a regionális politika szükségességét magyarázta felszólalásában. Gondolatmenete a kumulációs elvre épült. Eszerint egyes tevékenységek, régiók és országok mind jobb és jobb helyzetbe kerülnek, miközben mások pozíciói és lehetôségei egyre inkább romlanak. E folyamatok pedig - amelyek a feltételezett egyensúlyi helyzetektốl való elsodródással jellemezhetôk — gazdaságpolitikai reagálást, alkalmas eszközöket igényelnek.

A hetvenes évek legelejének, majd a 80-as évtizednek a tory kormánya - a jóléti állam horizontális újraelosztást biztosító intézményeinek korlátozását és leépítését szolgáló politikája részeként - szúkítette az állami regionális beavatkozások körét, újrafogalmazta az állami foglalkoztatási feladatokat a gazdaság piaci szerkezete erôsítésének érdekében. A monetarista és szabadpiaci gazdaságpolitika - a neoliberális makroökonómia elvei alapján - a regionális fejlesztési kiadásokat drasztikusan megnyírbálta, közel felére csökkentette, a támogatandó térségek népességének aránya a korábbi 47\%-ról 28\%-ra csökkent. Hasonló regionális politikai fordulatok játszódtak le más liberális-konzervatív kormányzatok hatalomra jutása után is. $E$ kormányzatok gazdaságpolitikai orientációja, a követendó közgazdasági irányzatok, az állam szerepéról vallott felfogások módosították a regionális politikák formajját, tartalmát és intézményi rendszerét (1. táblázat).

1. TÁBLÁZAT

Pártpolitikák és regionális politikák

\begin{tabular}{|c|c|c|}
\hline & $\begin{array}{l}\text { KONZERVATÍV- } \\
\text { LIBERÁLIS }\end{array}$ & $\begin{array}{c}\text { SZOCIALISTA- } \\
\text { SZOCIÁLDEMOKRATA }\end{array}$ \\
\hline $\begin{array}{l}\text { POLITIKAI IDEOLÓGIA } \\
\text { ÉS GAZDASÁGFILOZÓFIA }\end{array}$ & $\begin{array}{l}\text { Szabad piac, gazdasági liberalizmus, } \\
\text { monetáris kontroll, állami feladatok } \\
\text { újrafogalmazása }\end{array}$ & $\begin{array}{l}\text { Új-keynesiánus gazdaságpolitika, } \\
\text { széleskörü szociális programok }\end{array}$ \\
\hline $\begin{array}{l}\text { A REGIONÁLIS PROBLÉMÁK } \\
\text { FELFOGÁSA }\end{array}$ & $\begin{array}{l}\text { Mikrogazdasági; oka a helyi ered- } \\
\text { ménytelenség és a társadalmi, gaz- } \\
\text { dasági rugalmatlanság }\end{array}$ & Strukturális; oka a tốkehiány \\
\hline $\begin{array}{l}\text { SZERKEZETÁTALAKÍTÁS } \\
\text { MEGKÖZELÍTÉSE }\end{array}$ & $\begin{array}{l}\text { Piacracionális alapok: a magánvál- } \\
\text { lalkozások támogatása adó- és sza- } \\
\text { bályozási eszközökkel; a munkaerố- } \\
\text { piac deregulációja }\end{array}$ & $\begin{array}{l}\text { Decentralizált beavatkozás, belsố } \\
\text { gazdasági megújulás, infrastruk- } \\
\text { túra-fejlesztés }\end{array}$ \\
\hline $\begin{array}{l}\text { A REGIONÁLIS POLITIKA } \\
\text { FORMÁJA }\end{array}$ & $\begin{array}{l}\text { Minimális és szelektív támogatás, a } \\
\text { szabadpiac helyi formáinak (vállal- } \\
\text { kozási övezetek, fejlesztési társasá- } \\
\text { gok) fejlesztése; gazdasági kényszer- } \\
\text { intézkedések lokális szinten, regio- } \\
\text { nális magán-közösségi fejlesztés }\end{array}$ & $\begin{array}{l}\text { Kiterjedt állami támogatások, re- } \\
\text { gionális ügynökségek, a helyi kor- } \\
\text { mányzatok átfogó beavatkozási le- } \\
\text { hetóségei a helyi gazdaságba }\end{array}$ \\
\hline
\end{tabular}


2. A neokeynesiánus és a liberális hatalmi-politikai küzdelmek mellett a regionális politikák módosulására, újrafogalmazására objektív gazdasági-szerkezeti változások is hatással voltak.

A fordista-taylorista tömegtermelésen nyugvó monopolista felhalmozás növekedési szakaszát a fejlett ipari államokban a differenciált piac húzóerejére építô, decentralizációs korszak váltotta fel. A monopolizálódás, a vállalati struktúra koncentrációs tendenciái megfordultak, gyarapodott a kisvállalkozások száma. A vállalati struktúra koncentrációjának megtorpanása mérsékelte az állami gazdaságpolitika közvetlen beavatkozási lehetôségét. Mivel a tốke mellett az információ vált a gazdaság elsődleges stratégiai erôforrásává - ez utóbbiak a gazdaság piaci rendjében kevésbé monopolizálhatók -, szélesebb út nyílik a gazdaságba való bekapcsolódásra. A gazdaság decentralizációs irányú szerkezetváltozása, a társadalmi és az ezzel összefüggố kulturális és életmódbeli differenciálódás a politikai szerkezetet is módosította. A politikai struktúra decentralizálása a politikai regionalizmusban és a helyi társadalmak szabad szervezôdésében öltött testet.

A posztindusztriális szakasz gazdaság- és társadalompolitikája hatással van a regionális politikákra is. A gazdasági növekedésre alapozott hagyományos területfejlesztési koncepciókat új programok kezdik felváltani. A regionális politika mind több eleme kapcsolódik a gazdasági szerkezet átalakításához.

A hagyományos és a szerkezetátalakítás-orientált regionális stratégiák jellemzőit a 2 . és 3 . táblázat illusztrálja.

\section{TÁBLÁZAT}

A hagyományos területfejlesztési politika jellemzói

(W. B. Stöhr 1989. alapján)

1. A mennyiségi növekedés uniformizált modellje

2. A társadalmi-politikai és ökológiai minôségi tényezốk hiánya

3. Mobilitás- és tốkeorientáció

4. A regionális források lefölözése

5. A vállalati funkciók térbeli átrendezốdése

6. Törekvés a régión kivuüli tényezók megszerzésére

7. A térbeli problémák átterelése a periférikus területekre

8. A nagyméretứ, energiaigényes rendszerek fejlesztése

9. A gazdasági és a politikai döntéshozás dimenzióinak elkülönülése

10. A regionális szabályozó képesség gyengülése, a helyi-regionális közösségek felbomlása

\section{TÁBLÁZAT}

Szerkezetátalakítás-orientált regionális stratégia

\begin{tabular}{|c|c|}
\hline A szerkezetátalakitás formája & A regionális politika elsổleges tárgya \\
\hline ÚJRAIPAROSÍTÁS (reindusztrializáció) & $\begin{array}{l}\text { Csúcstechnológiai ipar, innovatív tevékenységek, } \mathrm{K}+\mathrm{F} \text {, technológiai } \\
\text { transzferek, tudományos parkok (ÚJ HELYI GAZDASÁGOK) }\end{array}$ \\
\hline IPARI ÁTALAKÍTÁS & A meglévó „,érett” iparágak újraélesztése, piaci diverzifikáció \\
\hline TERCIERIZÁLÓ & A szolgáltatási szektor fejlesztése \\
\hline MUNKAERŐÁTKÉPZÉS & $\begin{array}{l}\text { Átképzó́központok, felnốttoktatás, rugalmas foglalkoztatási rend- } \\
\text { szerek }\end{array}$ \\
\hline INFRASTRUKTURÁLIS MEGÚJÍTÁS & $\begin{array}{l}\text { A múszaki, az üzleti (marketing, tanácsadó szolgáltatás, informatika) } \\
\text { és a szociális infrastruktúra fejlesztése }\end{array}$ \\
\hline PÉNZÜGYI ÚJJÁSZERVEZÉS & $\begin{array}{l}\text { Regionális és lokális pénzpiacok szervezése, kockázati tôke, vállal- } \\
\text { kozásélénkítő alapok }\end{array}$ \\
\hline
\end{tabular}


A szakmai és politikai viták kereszttüzében álló vélemények a regionális politika jövôjéról három jól elkülöníthetổ csoportba sorolhatók.

A regionális politika visszaszoritását valló nézeteken kívül a regionális politikát támadók két köre rajzolódik ki. Az egyik koncepció hívei a regionális politika gyökeres reformja, pozícióinak megerôsítése mellett érvelnek. A hangsúlyt a hagyományos regionális politika reviziójára és megerốsítésére helyezik, annak érdekében, hogy az képessé váljon az akut területi válságok felszámolására, a regressziv folyamatok visszafordítására. A regionális politika újraértékelt törekvéseinek a homlokterében továbbra is azok a célok állnak, amelyek pénzügyi támogatások révén igyekeznek a vállalkozókat olyan tevékenység folytatására ösztönözni, amit enélkül nem tennének meg az adott térségben. Kétségtelen annak a veszélye, hogy a regionális politika marginálissá válik.

E veszély viszont elhárítható, ha a vállalatoknak nyújtott ösztönzókön kívül a gazdasági környezet komplex átalakítását is céljai között szerepelteti. Azaz a tartós kilábalás elengedhetetlen feltételei közé sorolja a magas színvonalú infrastruktúrát, az emberi erốforrásokat.

A regionális politika újrafogalmazásának harmadik irányzata az előbbinél is komplexebb megközelítést igényel. Olyan széles alapokon álló regionális fejlesztési programok kidolgozása mellett foglal állást, amelyeket regionális beruházási programok is alátámasztanak. Mindezek szorosan integrálódnak a közkiadások megtervezésének a folyamatába. Ennek az elképzelésnek a hívei tulajdonképpen a regionális szintũ koordináció erôsítésében, a központi és a helyi kormányzatok összehangolt programjaiban látják az igazi megoldást. A kormányzat széttagolt szerveinek, a különbözổ minisztériumoknak és hatóságoknak, a terület társadalmi-gazdasági folyamataira befolyást gyakorló intézményeknek regionális értelemben vett széttagoltságát kívánják felszámolni (4. táblázat).

4. TÁBLÁZAT

Regionális politika jövóje

\begin{tabular}{|c|c|c|}
\hline Jellemzók & Hagyományos & $\dot{U} \mathbf{j}$ \\
\hline PROBLEMATIKUS RÉGIÓK & Kétpólusú: fejlett/fejletlen & $\begin{array}{l}\text { Soktényezốs (különbözó regiou.́lis- } \\
\text { strukturális gyengeségek) }\end{array}$ \\
\hline ALAPSTRATÉGIA & Regionális növekedés & Regionális innováció \\
\hline SZERVEZETI FORMA & Régióközi elosztás & $\begin{array}{l}\text { Belsố regionális erôforrások mozgó- } \\
\text { sítása }\end{array}$ \\
\hline \multirow[t]{5}{*}{ A POLITIKA TÁRGYA } & Tóke, anyag & Információ, technológia \\
\hline & Mennyiségi növekedés & Minổségi átalakulás \\
\hline & Gyáripar & $\begin{array}{l}\text { Szolgáltatások, ágazatközi kapcsola- } \\
\text { tok }\end{array}$ \\
\hline & Tervek & Programok \\
\hline & Kisszámú nagyvállalat & Sok kis- és középüzem \\
\hline \multirow[t]{2}{*}{ DINAMIKA } & $\begin{array}{l}\text { Térben állandó problematikus } \\
\text { régiók }\end{array}$ & $\begin{array}{l}\text { Térben változó problematikus térsé- } \\
\text { gek }\end{array}$ \\
\hline & $\begin{array}{l}\text { A növekedési pólusok stabil } \\
\text { hálózata }\end{array}$ & Spontán helyi erôforrásmobilizáció \\
\hline
\end{tabular}

A törekvések kiteljesedése két dimenzióban követel meg változásokat. Egyrészt a központi kormányzat szintjén az egész gépezet olyan átalakítása szükséges, amely a gazdaságpolitikába és az államháztartás tervezésébe teljes komplexitásában képes integrálni a regionális tényezô- 
ket. Másrészt a régiók szintjén is szükséges az alkalmas politikai-adminisztratív keretek kialakítása. Az erốforrásallokáció prioritásainak meghatározása, a politika végrehajtásának koordinálása, a feladatok komplexitását szervezetileg leképezni képes intézményrendszer kialakítása kardinális jelentôségû́.

3. A fejlett országok regionális politikáinak elemzésébôl azt a következtetést vonhatjuk le, hogy az országok döntổ többségében regionális alapokon álló preferenciális segítségnyújtási rendszer alakult ki, amely a munkaerổtöbblettel rendelkezố térségek akut gondjainak nem csak tüneti jellegử megoldására hivatott. Annak ellenére, hogy a gazdaságpolitikák a nemzeti méretũ gazdasági regeneráció feladataiból építkeznek, nem hagyják figyelmen kívül az országok adaptációs gondjainak térbeli vetületeit sem.

A központi kormányzatok átgondolták az intervenció, a tervezés és a struktúraátalakítás menedzselésének minden pozitív lehetôségét. Ma már nyilvánvaló, hogy a beavatkozások nélkül a növekedés vagy a foglalkoztatási mérleg régiók közötti diszparitásai nem tüntethetốk el. A teljesen magára hagyott gazdaságról alkotott neoliberális elképzelés nemcsak a régi feszültségek enyhítését tenné lehetetlenné, hanem új, súlyos problémákat is okozna.

A gazdasági nehézségekkel küszködổ területek fejlesztésére irányuló állami politika rendszerint a következõ szempontokat veszi figyelembe.

a) Az eddigieknél átfogóbb és komplexebb kritériumok alapján határozza meg a segitségre szoruló térségek körét. Az alkalmazott kritériumrendszer az alapvetổ munkaerốpiaci jelzốszámok és a munkaerơforrások adatain kívül magába foglalja a gazdasági szerkezet és a vállalati szervezetrendszer alapvetổ jellemzổit, az innováció hordozóinak jellegét és csomópontjait, valamint a környezeti-helyi adottságok és értékek indikátorait is. Igen fontos kritérium: ahhoz, hogy valamely terület segélyezhetốvé váljék, fel kell tudni mutatnia valamiféle gazdasági potenciálban jelentkezó elốnyt.

b) A regionális preferenciális támogatásoknak csak az lehet a célja, hogy elsốdlegesen a munkahelyek növekedését, illetve a foglalkoztatási lehetốségek egyensúlyát teremtsék meg. A regionális fejlesztési segélyeket rendszerint alávetik egy olyan korlátozásnak, amely az álláshelyenkénti legmagasabb költségek meghatározásán alapul. Ha az álláshely egy meghatározott limitnél magasabb összegel teremthetố meg, nem folyósítják a támogatást. Általános tapasztalat, hogy nagymértékben növekedett a tercier szektor fejlesztésének segélyezése, valamint regionális technológiafejlesztési alapokat hoztak létre az innovációs lehetôségek kiterjesztésére, illetve az innovatív feltételekhez kapcsolódó munkaerő-képzés támogatására.

c) A regionális támogatások a szelektivitás elvén alapulnak. A világos és koherens értékelési rendszeren nyugvó átfogó szelekció a regionális és a kistérségi stratégiák összehangolását is elổsegíti.

d) A regionális stratégiák végrehajtásának meghatározó elemei - a helyi és a regionális kormányzati szervek mellett - a különbözô fejlesztési ügynökségek és társaságok. E fejlesztési szervezetek állami vagy vegyes finanszírozású intézmények, feladatuk a problematikus térségek társadalmi-gazdasági fejlesztési programjainak kidolgozása, pénzügyi támogatása, tanácsadás és információszolgáltatás (Belgiumban 7, az NSZK-ban 50, Hollandiában 5, Írországban szintén 5 fejlesztési társaság mứködik).

A központi kormányok politikájának alárendelt, vagy azoktól független regionális gazdaságszervezố, tanácsadó-menedzselô intézmények a régiók belsố erơforrásainak feltárására, kon- 
centrálására, az ott mưködô vállalatok eszközeinek, létszámának jobb kihasználására, mobilitásuk fokozására irányuló feladatokat látnak el. E sokfunkciójú (munkaerôközvetítés, átképzés, marketing-piackutatás, információs szolgáltatások stb.) intézmények - amelyek többsége kiterjedt külföldi fiókhálózattal is rendelkezik — fontos szerepet játszanak a strukturális átalakításokhoz szükséges tôkejavak régióba áramlásának szervezésében.

e) A regionális gazdasági szerkezetátalakítás állami költségvetésbôl finanszírozott tételeit parlamenti kontrollnak vetik alá, rendszerint állandó parlamenti bizottság készíti elô a döntéseket, s a törvényben rögzített támogatási formák hosszabb idốtávra biztos kalkulációs alapot jelentenek a gazdálkodó—vállalkozó szervezetek számára.

Az állami regionális politika irányváltozása érzékelhetóen átalakította a területfejlesztés pénzügyi-ösztönzési rendszerét is. A regionális ösztönzési politika változásának egyik kiváltó oka az Európai Közösség országaiban a költségvetési kiadások csökkenése volt. Ennek következtében a hatékony regionális ösztönzés súlypontjai a korábbi automatikus megoldásokról a kizárólagos (diszkvecionális) ösztönzési formákra helyezôdnek át. Ez utóbbi ösztönzési forma, lévén, hogy a támogatások szigorú kritériumok alapján, nem , ajándékozási” jelleggel történnek - az állami eszközök takarékos és hatéknny felhasználását kényszeríti ki.

A regionális ösztönzés változásának másik vonása - és a hatékony regionális politika fontos vitakérdése - a regionális támogatási mechanizmusok centralizálása és decentralizálása közötti viszony alakulása. A korábbi központosított ösztönzési alapokat ma már az országok többségében decentralizálták. Annak ellenére, hogy sokhelyütt erôs a központi szervek ellenállása — a helyi szervek intellektuális alkalmatlanságára hivatkozva - a decentralizálás további szélesítésével szemben, Spanyolország és Olaszország kivételével ma már a decentralizált ösztönzési alapok vannak túlsúlyban.

Az ösztönzési rendszer múködésének harmadik lényeges vonása a regionális politika gazdasági környezetében gyökerezik. A magas munkanélküliségi rátát mutató régiókban - s a regionális politikák legfontosabb terepét ezek jelentik - az ösztönzés alapvetôen a tókeberuházásokra irányul. A tôkeorientált ösztönzés hatékonysága a munkaerổorientált támogatásokkal szemben ma már egyértelmúen bizonyított tény. Az EGK-országokban alkalmazott közel negyven ösztönzési forma közül mindössze kilenc irányul a munkaerô speciális támogatására.

Az ösztönzésorientált regionális politika negyedik alapkérdése az, hogy miként válasszák ki a támogatandó tevékenységi formák körét. Általános tendencia, hogy fokozatosan növekszik a tercier szféra támogatása. Portugália kivételével valamennyi országban változatos regionális támogatási formákban részesülnek az idegenforgalmi, az üzleti és tanácsadó szolgáltatási, az információfeldolgozási, a fogyasztási szolgáltatási fejlesztések és a K-F tevékenység. Az ipari ágazatoknak nyújtott támogatások döntố része a feldolgozóiparba jut, a kitermelố- és alapanyaggyártó ipar részesedése elenyészô, igen ritka az építōipar és a mezôgazdasági termelés regionális ösztönzôkkel való támogatása (5. táblázat).

Az ösztōnzési formák, a szelektív és decentralizált ágazati támogatások egyenes következménye, hogy a szerkezetátalakítások legfontosabb bázisa valamennyi országban a kis-és középvállalati szféra. Az általános gazdaságpolitika befolyásolási mechanizmusai és a regionális politika érdekeltségi szférájának a metszéspontjában álló eme vállalati forma a nyugat-európai gazdasági struktúra átalakításának motorja. A gazdasági szerkezet megváltoztatásának minôségi követelményei módosították az iparpolitikai elképzeléseket is. Az új ipari stratégiák homlokteré- 
be két, egymással szoros kapcsolatban álló fejlesztési irányzat került: egyfelốl az ún. de-indusztralizációs folyamat (azaz a 19. században telepített ,kéményes” ipar visszafejlesztése), másrészt a re-indusztrializáció beindítása (csúcstechnológiát gyártó üzemek telepítése, a termelés komputerizálása, a robottechnikák elterjesztése stb.). A globális gazdaságpolitika a kisés középüzemek fejlốdéséhez kedvezô általános társadalmi-gazdasági környezetet teremtett, deregulációs politikával igyekezett kiiktatni a müködésüket gátló tényezổket.

5. TÁBLÁZAT

Fontosabb regionális ösztönzó́k az EGK-országokban, 1984

\begin{tabular}{|c|c|c|c|}
\hline Megnevezés & Ösztönzési forma & Támogatott ágazat & $\begin{array}{c}\text { Az odaítélt } \\
\text { támogatások száma }\end{array}$ \\
\hline \multirow[t]{2}{*}{ Belgium } & Kamatkedvezmény (Flandriában) & K, F, É, SZ, I & 361 \\
\hline & Kamatkedvezmény (Vallóniában) & $\mathrm{K}, \mathrm{F}, \mathrm{E}, \mathrm{SZ}, \mathrm{I}$ & 129 \\
\hline \multirow[t]{2}{*}{ Dánia } & Beruházási juttatás & F & 96 \\
\hline & Kedvezményes hitel & F & 8 \\
\hline \multirow[t]{3}{*}{ Franciaország } & Regionális politika alap & $\mathrm{F}, \mathrm{SZ}, \mathrm{I}$ & 827 \\
\hline & Regionális foglalkoztatási alap & F, SZ, I & \\
\hline & Helyi vállalkozási adókedvezmény & F, SZ, I & 222 \\
\hline \multirow[t]{4}{*}{ NSZK } & Beruházási kedvezmény & $\mathbf{K}, \mathbf{F}, \mathbf{I}$ & 2580 \\
\hline & Beruházási alap & $\mathrm{F}, \mathrm{I}$ & 923 \\
\hline & Különleges amortizáció & K, F, É, SZ, I & 15901 \\
\hline & Kedvezményes hitel & É, SZ, I & 10674 \\
\hline \multirow[t]{2}{*}{ Írország } & Iparfejlesztési alap & $\mathrm{F}$ & 238 \\
\hline & Nemzetközi szolgáltatási program & SZ & 26 \\
\hline \multirow[t]{3}{*}{ Olaszország } & Dél-Alap & F, SZ & 2710 \\
\hline & Kedvezményes hitel & F, SZ & . \\
\hline & Társadalombiztosítási kedvezmény & F, SZ, I & . \\
\hline \multirow[t]{2}{*}{ Hollandia } & Beruházási prémium & F, SZ & 206 \\
\hline & Termelôeszköz hitel & F, I & 151 \\
\hline
\end{tabular}

Jelmagyarázat: É = építôipar, $\mathrm{F}=$ feldolgozóipar, $\mathrm{I}=$ idegenforgalom, $\mathrm{K}=$ kitermelổpar, $\mathrm{SZ}=$ szolgáltatások Forrás: Yuill, $D .-$ Allen, $K$. 1988. alapján saját feldolgozás.

Az országos struktúraátalakító programokkal párhuzamosan - sốt sokszor azoktól függetlenül vagy azokat megelốzve - alakították ki a helyi és a regionális kormányzatok saját iparpolitikájukat. Számtalan esetben központi anyagi segítség nélkül kényszerültek új iparpolitikai eszközök igénybevételére. A helyi megoldások jelentôségét a termelés újjászervezésének sürgetổ igénye (a hanyatló ipari tevékenységek miatt kialakuló munkanélküliség politikai destabilizálódást okozó veszélye) miatt ismerték fel, ez magyarázza kidolgozásuk szükségességét is. Az alkalmazott eszközök körét természetesen befolyásolja a helyi kormányzatok korlátozott hatalma. Olyan új koncepciókat kellett kidolgozni, amelyek figyelembe veszik ugyan az adott terület adottságait, gazdasági érdekeit és problémáit, de korlátozott anyagi támogatási forrásokkal rendelkeznek. A helyi kormányzatok vállalták azt a szerepet, hogy új vállalatok alapításának a szervezésével, új termelési körök meghonosításával hozzájáruljanak területük gazdaságának revitalizálásához. Gazdaságfejlesztố tevékenységükben fontos együttmúködési partnereik a különbözổ üzleti csoportok, pénzügyi körök, ritkábban nagyvállalatok is. 
Természetesen a központi kormányok ezeket a törekvéseket a jogi garanciák, a gazdasági hatalom decentralizálását elôsegítő törvények segítségével igyekeznek támogatni. Lehetôvé vált - például Olaszországban -, hogy a helyi kormányzatok fejlesztési pénzintézeteket alapítsanak, amelyek a helyi ipart pénzügyi támogatásban részesítik, és sok esetben közvetlenül is érdekeltek a vállalkozásokban. A helyi-regionális szervek szinte valamennyi tartományban müszaki szolgáltató központokat alapítottak, amelyek új technológiák terjesztésével és magas munkaigényességũ egyéb szolgáltatásokkal állnak a kis-és középvállalatok rendelkezésére. Tartományonként 6-8 szolgáltató központot találunk.

Ezek a példák is azt bizonyítják, hogy mind a területi gazdasági szerkezet átalakításában, mind pedig ebben lényegesen szerepet játszó kis- és középvállalati struktúra megteremtésében a hagyományos intézményrendszer mellett új speciális szervezetek kialakitására is szükség van. A szerkezeti változások ösztönzése és szervezése több - önkormányzati, igazgatási, üzleti és pénzügyi - szervezet együttmüködésével valósitható meg.

\section{Irodalom}

Armstrong, H. - Taylor J. (1985) Regional Economics and Policy, Philip Allen, Oxford.

Balchin, P. N. - Bull, G. H. (1987) Regional and Urban Economics, Harper and Row, London.

Dunford, M. F. (1988) Capital, the State and Regional Development. Pion, London.

Frankel, B. (1987) The Post-Industrial Utopians. Policy Press, London.

Hudson, R. (1989) Wrecking a Region. State Policies, Party Politics and Regional Change. Pion, London.

Káldor, M. (1989) Gazdaságelmélet-gazdaságpolitika. Közgazdasági és Jogi Könyvkiadó, Budapest.

Keating, M. (1989) Local Goverment and Economic Development in Western Europe, Entrepneurship and Regional Development, 3.

Muegge, H. - Stöhr, W. B. (szerk.) (1987) International Economic Restructuring at the Regional Community, Gower, Hampshire.

Stöhr, W. B. (1989) Global Challenge and Local Response, Learning Experiences of Local Development Initiatives in Contemporary Europe, Cassell-Tycooly, London.

Yuill, D. - Allen, K. - Bachtler, J. - Wishlade, F. (1988) European Regional Incentives, University of Strathclyde, Glasgow. 
Horváth Gyula: Válaszút elött a regionális politika.

Tér és Társadalom, 5. 1991. 1.117-123. $p$.

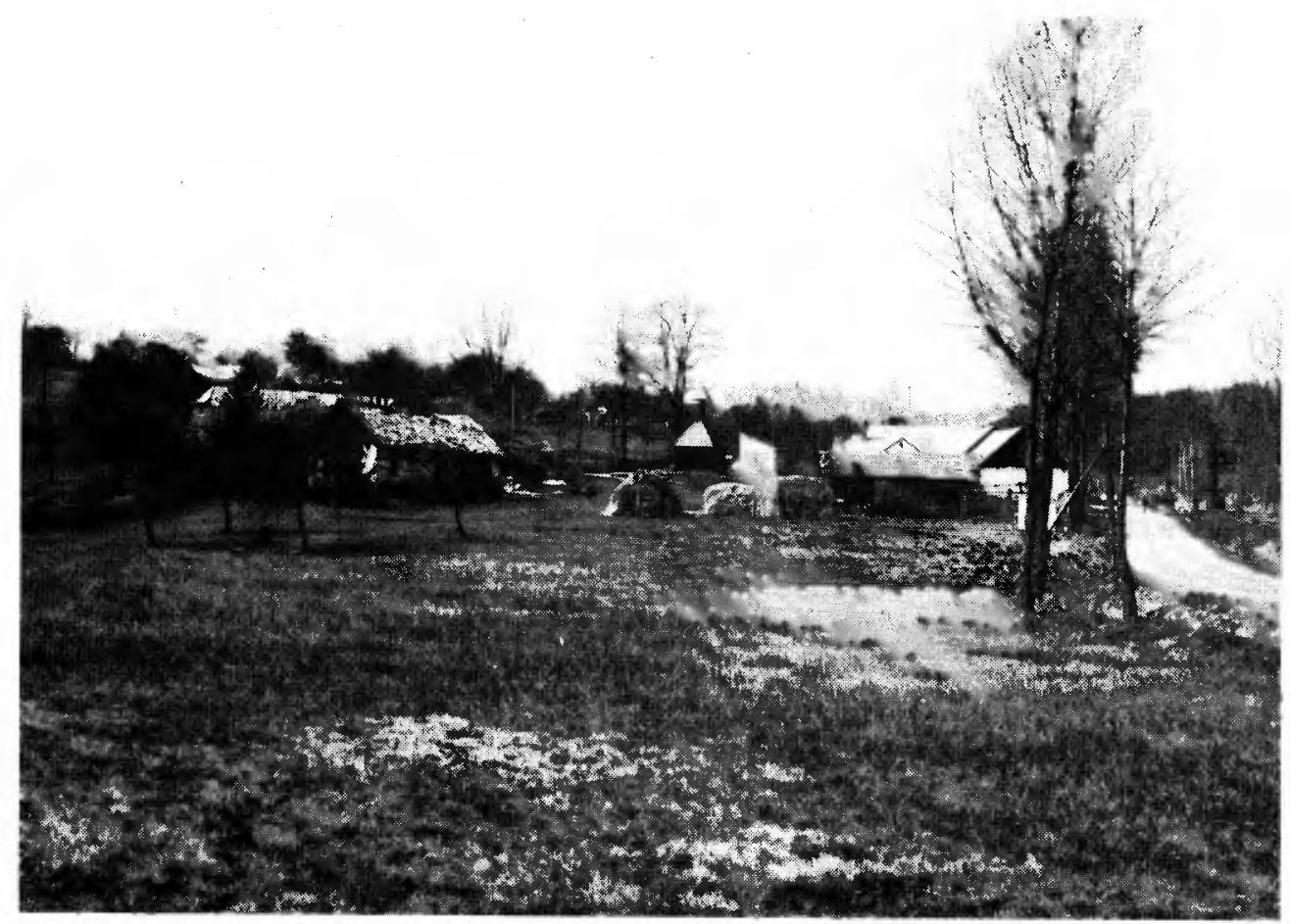

Szórványok közelrôt; a szlovén határon fekvố vendlakta Orfalu. 